\title{
IDENTIFIKASI KESALAHAN MAHASISWA DALAM MELAKSANAKAN PRAKTIKUM PADA MATAKULIAH KONSEP IPA 2 DI PRODI PGSD FIP IKIP PGRI MADIUN
}

\author{
Edy Riyanto *
}

\begin{abstract}
This study aims to identify kinds of mistake by students, and those contributing most in carrying out the practicum in the class of Konsep IPA 2 second term in the academic year of 2011/2012. The subjects are those attending the class as many as 40. Data were collected through an observation focusing on the types of mistakes done by the subjects while they were doing their practicum. The mistakes observed cover mistake of tools, the tool positions, arranging the tools, determining the units, the scales, and the zero point. Results show mistakes of arranging the tools reaching 60\%, of parallax and determining the scale amounting 50\%, on determining the zero point amounting 35\%, on positions $27.5 \%$, on the units $30 \%$, on tools $17.5 \%$, and on figures $12.5 \%$. The major mistakes done by the subject are on arranging the tools.
\end{abstract}

Key words: Students' Mistakes, Practicum

\begin{abstract}
Abstrak
Penelitian ini bertujuan untuk mengidentifikasi jenis-jenis kesalahan yang sering dilakukan oleh mahasiswa, serta jenis kesalahan yang memberikan proporsi terbesar dalam pelaksanaan praktikum pada mata kuliah Konsep IPA 2. Penelitian dilaksanakan di Prodi PGSD semester genap tahun akademik 2011/2012. Subjek penelitian ini berjumlah 40 mahasiswa semester 2 yang mengikuti mata kuliah Konsep IPA 2. Teknik penambilan data penelitian ini menggunakan teknik observasi. Pengamatan dilakukan terhadap kesalahan yang dilakukan mahasiswa ketika melaksanakan praktikum. Kesalahankesalahan yang diamati meliputi: keadaan alat, posisi alat, merangkai alat, paralaks, penentuan skala, menentukan satuan, angka berarti, dan titik nol. Hasil penelitian menunjukkan bahwa kesalahankesalahan yang sering dilakukan oleh mahasiswa melaksanakan praktikum Konsep IPA 2 adalah: kesalahan merangkai alat sebanyak $60 \%$; kesalahan paralaks dan kesalahan penentuan skala masingmasing sebanyak 50\%; kesalahan titik nol sebanyak 35\%; kesalahan posisi alatsebanyak $27,5 \%$; kesalahan menentukan satuan sebanyak $30 \%$; kesalahan keadaan alat saat bekerja sebanyak 17,5\%; dan kesalahan angka berarti sebanyak 12,5\%. Kesalahan yang memiliki
\end{abstract}

* Edy Riyanto adalah Dosen Program Studi PGSD FIP IKIP PGRI Madiun 
proporsi terbesar yang dilakukan oleh mahasiswa melaksanakan praktikum Konsep IPA 2 ialah kesalahan merangkai alat.

Kata kunci: Kesalahan Mahasiswa, Praktikum

\section{A. Pendahuluan}

Ilmu Pengetahuan Alam (IPA) merupakan usaha manusia dalam memahamialam semesta melalui pengamatan yang tepat (correct) pada sasaran, sertamenggunakan prosedur yang benar (true), dan dijelaskan dengan penalaran yangsahih (valid) sehingga dihasilkan kesimpulan yang betul (Sutrisno, 2007: 119). Menurut Slamet, dkk. (2008:1.1) IPA merupakan cabang ilmu pengetahuan yang mempelajari tentang fenomena-fenomena alam yang disusun melalui tahapan-tahapan metode ilmiah yang bersifat khas-khusus, yaitu penyusunan hipotesis, melakukan observasi, penyusunan teori, pengujian hipotesis, penarikan kesimpulan, dan seterusnya.

Williams (2011:8) menyatakan "in understanding the nature of science we must necessarily look at its history and development and learn something about those who have worked in the past and who currently work in the realms of science, the scientist". Pernyataan tersebut menggambarkan tentang bagaimana cara kerja IPA yang secara sederhana dapat dilihat pada Gambar 1.

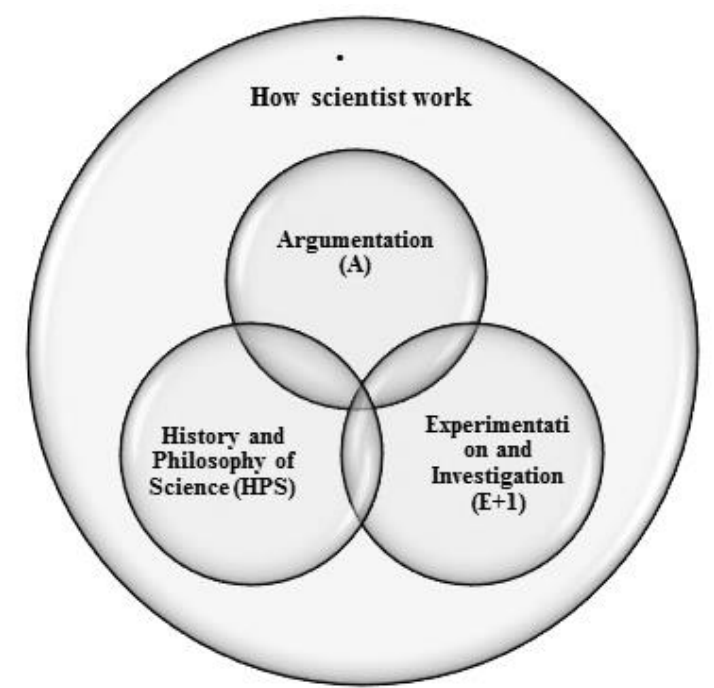

\section{Gambar 1 Model Cara Kerja IPA (Williams, 2011:74)}

Untuk mendukung definisi di atas, salah satu faktor yang sangat menunjang keberhasilan pendidikan IPA adalah laboratorium. Melalui kegiatan praktik di laboratorium dapat diperlihatkan gejala-gejala IPA yang dibahas baik yang sesungguhnya maupun yang berbentuk model sehingga daya serap mahasiswa terhadap materi lebih meningkat. Disamping itu kegiatan eksperimen dapat memupuk sikap mandiri, etos kerja, dan sikap ilmiah mahasiswa. Naim (1992: 3-10) menyatakan bahwa manfaat kegiatan praktikum di laboratorium ialah memupuk sikap mandiri dan tempat melatih keterampilan. 
Keberadaan laboratorium memang sangat dirasakan manfaatnya. Hal ini tidak mengherankan mengingat fungsi laboratorium sebagai tempat menguji teoriteori IPA yang diajarkan oleh guru maupun dosen. Manfaat praktikum seperti yang dikemukakan oleh Amin (1998:95) bahwa kegiatan praktikum dapat diartikan sebagai salah satu strategi belajar-mengajar dengan menggunakan pendekatan ilmiah terhadap gejala-gejala baik gejala sosial psikis maupun percobaan atau penelitian di bawah kondisi yang diatur melalui praktikum.

Melalui kegiatan praktikum ini mahasiswa akan dapat melatih keterampilkan berpikir ilmiah, dapat menentukan dan memecahkan masalah melalui metode ilmiah. Rustaman mengemukakan empat alasan pentingnya kegiatan praktikum IPA, yaitu: (1) praktikum membangkitkan motivasi belajar IPA; (2) praktikum mengembangkan keterampilan dasar melakukan eksperimen; (3) praktikum menjadi wahana belajar pendekatan ilmiah; dan (4) praktikum menunjang materi pelajaran (Sugiharto, 2008:1). Mahasiswa dalam melaksanakan praktikum dapat secara langsung mengamati proses IPA sehingga pemahaman konsep-konsep akan lebih mudah diingat. Mengingat pentingnya pelaksanaan praktikum, maka baik dosen maupun mahasiswa dituntut perannya dalam kegiatan ini, agar apa yang menjadi tujuan pelaksanaan praktikum dapat terwujud dan tidak terjadi hal yang tidak diinginkan.

Namun hal ini bisa saja terjadi diakibatkan oleh beberapa faktor antara lain mahasiswa tidak siap melaksanakan praktikum, kurang terampil dalam mengoperasikan alat-alat, mahasiswa kurang bahkan tidak pernah melaksanakan praktikum pada saat di sekolah menengah. Dari beberapa kekurangmampuan mahasiswa dalam pelaksanaan praktikum ini, maka sudah tentu banyak melaksanakan kesalahan-kesalahan seperti kesalahan dalam pengamatan, kesalahan sistematik, dan kesalahan acak.

Kegiatan praktikum merupakan syarat dalam mata kuliah konsep IPA 2 yang selain materi disajikan secara teoritik juga disyaratkan untuk kegiatan praktikum. Mata kuliah Konsep IPA merupakan matakuliah yang mengkaji konsep-konsep dasar IPA (Fisika dan Kimia) yang meliputi: pengukuran, materi dan perubahannya, energi dan perubahannya; sumber daya alam, bumi dan alam semesta, pengukuran, listrik, dan kemagnetan serta cahaya; pembuatan laporan praktikum pengukuran, listrik, kemagnetan, dan cahaya; serta penanaman sikap pelestarian lingkungan.

Berdasarkan fenomena di atas, maka peneliti mengidentifikasi jenis-jenis kesalahan yang sering dilakukan oleh mahasiswa, serta jenis kesalahan yang memberikan proporsi terbesar dalam pelaksanaan praktikum Konsep IPA 2.

\section{B. Praktikum Ilmu Pengetahuan Alam}

Praktikum IPA adalah kegiatan praktik/percobaan/observasi yang dilakukan untuk membuktikan konsep dan teori IPA. Sutarno (2005: 8.18) mengemukakan bahwa IPA merupakan hasil kegiatan manusia berupa pengetahuan, pengalaman melalui serangkaian proses ilmiah seperti penyelidikan, penyusunan, dan pengujian gagasan. Oleh karena itu dalam pembelajaran perlu membangun pengetahuan siswa. Dalam pembelajaran IPA siswa hendaknya dilibatkan dalam kegiatan langsung pada objek nyata, karena akan membantu 
siswa untuk berfikir melalui pengalaman belajarnya. Levinson (2005:15) mengemukakan pentingnya praktikum dalam IPA sebagai berikut:

Simply belongs there as naturally as cooking belongs in a kitchen and gardening in a garden. Books of recipes or gardening manuals can be read anywhere, but the smells, taste, labour and atmosphere can only be evoked in those who already know the reality. It is the same with science, and so the teaching of it must involve real contact with those aspects of nature which are to be studied.

Segala sesuatu yang telah diketahui tentang dunia IPA dan tentang prinsipprinsip yang mengatur sifat-sifat yang dipelajari melalui percobaan atau praktikum, yaitu dengan pengamatan terhadap gejala-gejala alam. Gejala-gejala alam yang sukar ditemukan, yang tidak bisa diamati dari dekat dan sulit diamati karena waktunya cepat bagi mata kita, dibuat modelnya dalam laboratorium. Kondis-kondisinya diatur sedemikian hingga sesuai dengan gejala alam yang sebenarnya serta proses dan hasilnya diamati atau diukur kemudian hasil pengukuran itu diolah. Dari hasil pengolahan inilah dapat ditarik kesimpulan apakah suatu teori memiliki kebenaran sesuai dengan gejala alam atau tidak (Wirasasmita, 1999: 1-3).

Banyak manfaat yang bisa diperoleh dalam pembelajaran IPA melalui praktikum. Osborne dan Dillon (2010:113) menyatakan:

I will consider in turn the research evidence concerning the use and effectiveness of practical work: to enhance the learning of scientific knowledge; to teach laboratory skills; to give insight into scientific method, and develop expertise inusing it; in stimulating students' interest and increasing motivation to studyscience; and in developing understanding of the nature of science.

Dengan adanya kegiatan praktikum maka mahasiswa atau siswa diharapkan lebih mudah mempelajari pelajaran IPA, karena mereka dapat membandingkan teori-teori yang diajarkan dengan hasil percobaan yang diperolehnya di laboratorium. Di samping itu juga kegiatan praktikum dapat mendidika mahasiswa bersikap mandiri, ilmiah, dapat memecahkan masalah dan melatih keterampilan. Dengan demikian pembelajaran melalui pendekatan praktikum bertujuan: (1) mendorong dan mempertahankan minat, sikap yang baik, kepuasan, keterbukaan, dan rasa ingin tahu tentang IPA; (2) mengembangkan pikiran yang kreatif dan kemampuan untuk memecahkan masalah; (3) medorong berbagai aspek dari pikiran keilmuan termasuk bagian-bagian metoda IPA seperti merumuskan hipotesa dan anggapan; (4) mengembangkan pemahaman konsep dan potensi intelektual; (5) mengembangkan keterampilan proses seperti merancang dan melakukan penyelidikan, pengukuran, merekam data, menganalisa dan menafsirkan hasil percobaan; dan (6) mengembangkan keterampilan dalam menggunakan teknik-teknik eksperimental dan penggunaan alat seperti multimeter, mikroskop, titrasi, dan merangkai alat.

Menurut tujuannya, pembelajaran melalui pendekatan praktikum dibedakan menjadi tiga yaitu: (1) praktikum konsep menekankan perkembangan 
konsepsiswa dan penanggulangan miskonsepsi; (2) praktikum konsep menekankan latihan keterampilan proses, yaitu keterampilan yang digunakan untuk mencari dan mengesahkan pengetahuan melalui eksperimen; dan (3) praktikum keterampilan menekankan latihan penggunaan peralatan dan teknikteknik eksperimental seperti pengukuran dengan multimeter dan stopwatch, menyolder, merancang peralatan.

Melaksanakan praktikum berarti melakukan pengukuran. Pengukuran merupakan pengumpulan informasi, dengan melakukan pengumpulan dapat diperoleh besarnya suaatu besaran, dan juga diperoleh bukti yang kualitatif. Namun dalam pengamatan suatu gejala pada umumnya belumlah lengkap jika belum memberikan informasi yang kuantitatif, sehingga untuk memperoleh informasi tersebut memerlukan pengukuran suatu sifat fisis (Soejoto dan Sustini 1983: 1). Dari pengukuran itu diperoleh berbagai sumber diolah dan disintesiskan menjadi sebuah model atau teori suatu gejala alam. Agar berguna teori, teori harus menerangkan semua peristiwa alam yang dikenal waktu itu, bahkan harus dapat meramalkan berbagai hal baru yang benar tidaknya dibuktikan dengan percobaan dan pengukuran baru (Djonoputro, 1984:1).

Dalam melakukan pengukuran setiap orang hendaknya memahami arti dari sebuah pengukuran. Tanpa memahaami pengukuran besar kemungkinan dalam melakukan percobaan akan banyak terjadi kesalahan. Hampir semua orang pernah bahkan sering melakukan pengukuran, seperti pedagang di toko mengukur panjang kain yang akan dijual dengan menggunakan alat ukur panjang. Dokter mengukur temperatur pasiennya dengan menggunakan temperatur. Jadi pengukuran adalah membandingkan suatu besaran dengan besaran lain yang dijadikan sebagai acuan (Wirasasmita, 1999:9).

Sedangkan menurut Soejoto dan Sustini (1993:1) pengukuran adalah suatu tehnik menyatakan suatu sifat fisis dalam bilangan sebagai hasil membandingkannya dengan suatu besaran baku yang diterima sebagai satuan. Dalam pengukuran sering terjadi kesalahan yang dilakukan oleh peserta, kesalahan tersebut terdiri:

\section{Kesalahan Sistematik}

Kesalahan sistematik adalah kesalahan yang harganya tetap dalam sekumpulan pembacaan suatu besaran. Jika terjadi kesalaha sistematik maka sebarannya tidak pada sekitar harga yang sebenarnya, tetapi sekitar suatu harga yang bergeser dari harga yang sebenarnya (Wirasasmita, 1999: 19-20). Kesalahan acak bisa dicacah (dideteksi) dengan mengulang-ulang percobaan. Selain itu dengan pengukuran berulang-ulang didapat suatu harga rata-rata yang makin mendekati harga yang sebenarnya. Hal ini tidak berlaku pada kesalahan sistematik. Pengukuran berulan dengan menggunakan alat yang sama tidak dapat menampakkan atau menghilangkan kesalahan sistematik, karna itu kesalahan sistematik lebih membahayakan dari pada kesalahan acak. Adanya kesalahan sistematik yang tersembunyi akan membuahkan hasil yang kelihatannya dapat dipercaya dengan kesalahan taksiran yang kecil, yang sebenarnya kesalahan yang besar. 
Kesalahan seperti ini pernah dilakukan oleh Millikan dalam percobaan tetes minyak untuk mengukur muatan elektron. Dalam percobaan ini diperlukan harga viksositas udara. Karena harga viksositas udara yang digunakan oleh Millikan terlalu rendah maka hasil pengukuran muatan elektron besarnya: $\mathrm{e}=$ $(1,591 \pm 0,002) \cdot 10^{-19}$ Coloumb. Pengukuran yang sama dilakukan oleh Cohen dan Taylor pada tahun 1923, dan diperoleh harga: $\mathrm{e}=(1,602 \pm 0,000005) \cdot 10^{-19}$ Coloumb. Sampai tahun 1930 harga beberapa atom yang lain, seperti konstanta Planck dan konstanta Avogadro, berdasarkan harga muatan elektron yang diperoleh Millikan sehingga kesalahannya lebih dari 0,5\%.

Kesalahan sistematik menurut Wirasasmita (1999:21-25) digolongkan kedalam tiga jenis:

a. Kesalahan alami timbul dari gejala-gejala alam yang merupakan akibat-akibat dan pengaruh tertentu yang bekerja pengamat melihat atau membaca secara langsung besaran-besaran yang dicari. Misalnya alat yang digunakan untuk mengukur jarak antara dua titik dengan menggunakan gelombang radio akan menunjukkan hasil ayng kurang tepatbila tidak tidak dilakukan koreksi akan pengaruh tekanan dan kandungan uap air dalam udara terhadap kecepatan gelombang radio;

b. Kesalahan alat alat merupakan pengaruh ketidaksempurnaan kontruksi atau pengaturan alat yang digunakan dalam pengukuran. Hal yang bisa terjadi diantaranya dalam memberi garis-garis skala. Kesalahan karena kurang sempurnanya komponen optik dalam teleskop, dan gesekan pada tumpuan jarum petunjuk. Contohnya penunjukan jarum pada amperemeter yang terlalu rendah karena gesekan pada porosnya terlalu besar;

c. Kesalahan perorangan yang bergantung pada keterbatasan jasamani dan juga pada kebiasaan pengamat yang mungkin disebabkan oleh kelambatan pendengaran dalam menerima tanda (signal) waktu, sedikit kecendrungan terlalu kekiriatau kekanan dalam menaksir skala terkecil pada alat, atau pada kurang baiknya penglihatan, misalnya pada waktu membaca jangka sorong.

Menurut Djonoputro (1994:3-4) kesalahan sistematik digolongkan menjadi enam bagian:

a. Kesalahan Kalibrasi yaitu cara memberi nilai skala pada waktu pembuatan alat tidak tepat sehingga setiap kali digunakan, suatu ketidakpastian melekat pada hasil pengukuran. Keadaan ini dapat diketahui dengan cara membandingkan alat tersebut dengan alat baku;

b. Kesalahan titik nol yaitu titik nol skala tidak berimpit dengan titik nol jarum petunjuk atau jarum tidak kembali tepat pada angka nol;

c. Kesalahan komponen alat misalnya dalam pegas yang telah dipakai beberapa lama dapat agak melembek hingga dapat mempengaruhi gerak jarum penunjuk.

d. Gesekan adalah selalu timbul antara bagian yang satu dan bergeser terhadap bagian alat yang lain;

e. Paralaks yaitu kesalahan yang timbul apabila pada waktu membaca skala, pengamat tidak tegak lurus di atas jarum petunjuk. Banyak alat ukur yang memakai jarum penunjuk dilengkapi suatu cermin yang terpasang di bawah jarum untuk menghindari paralaks, misalnya ammeter; 
f. Keadaan saat bekerja yaitu pemakaian alat dalam keadaan yang berbeda dengan keadaan alat pada saat dikalibrasi (suhu, tekanan, dan kelembaban udara yang berbeda) akan menyebabkan terjadinya kesalahan.

\section{Kesalahan Rambang (Acak)}

Kesalahan rambang (acak) adalah kesalahan yang berubah-ubah seolaholah positif dan negatif (Wirasasmita, 1999: 19). Kesalahan ini timbul karena kondisi lingkungan yang tidak menentu dan menggganggu kerja alat kita, sehinggakesalahan ini terjadi selalu terjadi dalam setiap percobaan yang menyebabkan pembacaan yang menyebar sekitar harga yang sebenarnya suatu besaran. Djonoputro (1984: 4-5) menyebutkan beberapa kesalahan acak (rambang) sebagai berikut:

a. Gerak Brown molekul udara seperti dimaklumi, molekul udara (molekul $\mathrm{N}_{2}$, $\mathrm{O}_{2}$, dan $\mathrm{Cl}_{2}$ ) senantiasa dalam keadaan bergerak yang sangat tidak teratur sifatnya (gerak rambang). Gerak ini pada saat-saat tidak ditentukan mengalami fluktuasi dalam arti jumlah molekul yang bergerak kesuatu arah senantiasa secara tiba-tiba dapat menjadi besar atau kecil. Ini yang menyebabkan penunjukan jarum alat yang sangat halus (seperti mikrometer) terganggu karena tumbukan molekul udara;

b. Fluktuasi pada tegangan jarum listrik, jika tegangan PLN atau yang kita peroleh dari accu (aki) atau baterai selalu berfluktuasi, yaitu mengalami perubahan kecil yang tidak teratur (rambang) dan berlalu sangat cepat. Ini jelas mengganggu pengukuran listrik;

c. Landasan yang bergetar yaitu alat yang sangat peka dapat terganggu oleh landasan yang bergetar. Seperti dimaklumi kerak bumi selalu berada dalam keadaan bergetar karena hempasan ombak samudra terus menerus dan kesibukan lalu lintas;

d. Asing adalah gangguan yang selalu kita dapatkan pada alat elektronik. Ia berupa fluktuasi yang cepat dalam alat karena komponen alat bersuhu;

e. Radiasi latar belakang yaitu radiasi kosmos dari angkasa luar dapat merupakan gangguan pada pengukuran dengan alat pencacah karena akan terhitung sewaktu kita mengukur dengan pencacah elektronik.

\section{Kesalahan Pengamatan}

Dalam jaman teknologi sekarang ini, banyak peralatan yang rumit operasinya sudah masuk laboratorium sekolah atau universitas. Pemakaiannya memerlukan ketangkasan dan keterampilan yang tinggi. Misalnya pengukuran dengan spektrometer optik tidak mudah dan sederhana. Banyak yang harus disambung sebelum alat siap dipakai dan makin banyak yang harus diatur makin besar kemungkinan orang membuat kesalahan (Djonoputro, 1984:5). Sehingga di sini diperlukan keterampilan pengamat dalam mebaca skala. Besarnya kesalahan membaca ini dipengaruhi oleh kemampuan kita menaksir besar kecilnya jarak antara dua garis skala, dan bergantung pada kedudukan mata kita.

Kesalahan yang sering dilakukan oleh pengamat ialah: (a) merangkai alat yaitu jika dalam pengukuran atau percobaan diperlukan keterampilan yang tinggi, karena pada umumnya alat-alat yang digunakan di laboratorium sekarang ini 
adalah alat-alat yang canggih, sehingga sebelum melakukan percobaan alat-alat harus dirangkaikan. Kesalahan merangkai alat dapat mengakibatkan kerusakan alat; (b) kesalahan menggunakan satuan yaitu jika pada alat ukur seperti multimeter digital terdapat berberapa fungsi dan satuan yang berbeda, sehingga dalam menggunakannya diperlukan ketelitian. Misalnya dalam mengukur arus listrik, mengukur hambatan, dan mengukur tegangan diperlukan perubahan satuan; (c) penulisan angka penting disebabkan oleh penggunaan alat yang canggih dan keterampilan pengamat yang kurang. Misalnya hasil pengukuran panjang balok 17,50 $\mathrm{cm}$ dan 17,5 $\mathrm{cm}$. Mungkin ada yang berpendapat bahwa kedua nilai di atas adalah sama, padahal sesuai dengan aturan penulisan angka penting bahwa angka penting tersebut terdiri dari angka pasti dan angka tafsiran. Sehingga jelas bahwa kedua nilai di atas berbeda. Menaksir kesalahan merupakan hal yang sangat penting dilakukan sebab tanpa hal ini kita tidak bisa menarik kesimpulan yang berarti dari suatu hasil percobaan.

\section{Metode Penelitian}

Metode yang digunakan dalam penelitian ini adalah metode deskriptif untuk memperoleh gambaran mengenai jenis kesalahan yang sering dilakukan oleh mahasiswa dalam melaksanakan praktikum Konsep IPA 2. Subyek penelitian ini adalah mahasiswa Prodi PGSD peserta matakuliah Konsep IPA 2 semester genap tahun akademik 2011/2012 sebanyak 40 mahasiswa.

Pengumpulan data pada penelitian ini digunakan tehnik observasi langsung dengan instrumen lembar observasi berupa chek list. Melalui instrumen ini akan didapat data yang akurat dari variabel yang telah ditentukan yakni kesalahan yang dilakukan oleh mahasiswa dalam melaksanakan praktikum Konsep IPA 2.

\section{Hasil Penelitian}

Berdasarkan hasil chek list teridentifikasi jenis-jenis kesalahan yang sering dilakukan oleh mahasiswa dalam melaksanakan praktikum Konsep IPA 2. Hasil ini dikelola dalam bentuk persentase, yakni:

1. Kesalahan merangkai alat: jenis kesalahan ini berdasarkan hasil pengamatan menempati urutan tertinggi yakni dari 40 mahasiswa terdapat 24 (60\%) mahasiswa yang melakukan kesalahan merangkai alat;

2. Kesalahan Paralaks dan kesalahan penentuan skala: dua jenis kesalahan ini dari hasil pengamatan menempati urutan kedua yaitu dari 40 mahasiswa masingmasing 20 (50\%) mahasiswa yang melakukan kesalahan paralaks dan kesalahan penentuan skala;

3. Kesalahan titik nol: dari hasil pengamatan 40 mahasiswa diperoleh sebanyak $14(35 \%)$ mahasiswa yang melakukan kesalahan titik nol;

4. Kesalahan posisi alat: kesalahan ini menempati urutan keempat dimana dari 40mahasiswa terdapat $11(27,5 \%)$ mahasiswa yang melakukan kesalahan posisi alat;

5. Kesalahan menentukan satuan: kesalahan ini menempati urutan kelima dimana dari 40 mahasiswa terdapat 12 (30\%) mahasiswa yang melakukan kesalahan posisi alat; 
6. Kesalahan keadaan alat saat bekerja: kesalahan ini menempati urutan kelima yaitu dari 40 mahasiswa terdapat $7(17,5 \%)$ mahasiswa yang melakukan kesalahan;

7. Kesalahan angka berarti: kesalahan ini terdapat $5(12,5 \%)$ mahasiswa yang melakukan kesalahan dari 40 mahasiswa.

\section{E. Pembahasan}

Setelah dilakukan praktikum konsep IPA 2 di Prodi PGSD diketahui masih banyak mahasiswa yang berpendapat bahwa kegiatan praktikum ini sangat kecil manfaatnya dengan penguasaan materi. Pendapat-pendapat ini disebabkan oleh beberapa faktor diantaranya: (1) minimnya pengetahuan mahasiswa tentang alatalat praktikum dan fungsi dari alat tersebut; (2) mahasiswa kurang mampu mengaplikasikan antara teori yang didapatnya dengan hasil eksperimen; (3) kurangnya pelaksanaan praktikum pada matakuliah lain yang seharusnya juga dilaksanakan praktikum seperti konsep IPA 2, Pembelaran IPA; dan (4) kurangnya pelaksanaan praktikum bahkan tidak pernah dilaksanakan praktikum di sekolah-sekolah sebelumnya (SD, SMP, dan SMA), sehingga siswa-siswa lulusan tersebut tidak mampu bahkan tidak tahu dan tidak bisa mengoperasikan alat-alat praktikum pada saat praktikum berlangsung.

Ketidakmampuan mahasiswa dalam mengoperasikan alat-alat yang digunakan pada saat praktikum berlangsung, juga berpengaruh. Hal ini dapat dibuktikan dari hasil penelitian terdapat beberapa kesalahan yang dilakukan mahasiswa dalam melaksanakan praktikum. Kesalahan-kesalahan tersebut diantraranya kesalahan merangkai alat, kesalahan titik nol, kesalahan paralaks, kesalahan menggunakan satuan, kesalahan penentuan skala, dan kesalahan posisi alat. Kesalahan ini merupakan kesalahan yang mempengaruhi jalannya kegiatan praktikum dan hasil kesimpulan yang diperoleh dalam percobaan. Besarnya kesalahan yang dilakukan oleh mahasiswa dalam melaksanakan praktikum Konsep IPA 2 dari hasil penelitian dapat dilihat pada diagram berikut:

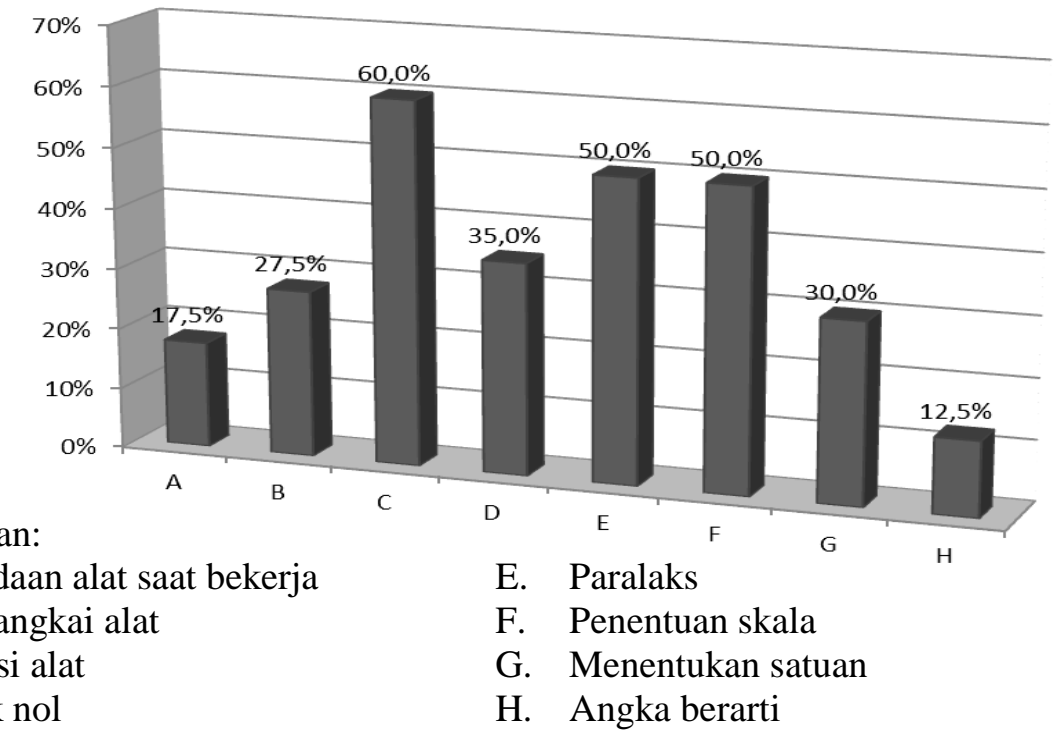

Gambar 2 Persentase Kesalahan Mahasiswa dalam Melaksanakan Praktikum 
Berdasarkan hasil yang di dapat dari penelitian di atas,masih banyak kesalahan yang dilakukan oleh mahasiswa dalam praktikum Konsep IPA 2 ini, sehingga sangat perlu untuk mendapatkan perhatian dari berbagai pihak yang terkait, karena ini akan berdampak negatif dan akan menhasilkan praktikanpraktikan yang kurang berkualitas, apalagi mereka nantinya kalau sudah menjadi pengajar tentu hasil didikannya tidak jauh berbeda dengan dirinya atau bahkan lebih rendah lagi.

Guna mengatasi hal tersebut di atas maka sangat perlu untuk meningkatkan kualitas pelaksanaan praktikum baik segi pengelolaan daan tenaga laboran maupun pada praktikan itu sendiri. Disamping itu perlu juga melaksanakan praktikum di jenjang sekolah, baik dasar maupun menengah, agar mahasiswa mempunyai pengetahuan dasar tentang alat-alat laboratorium. Tingginya atau besarnya kesalahan-kesalahan yang dilakuakn oleh mahasiswa dalam melaksanakan praktikum IPA dasar disebabkan karena pada umumnya praktikan tidak tahu alat-alat dan fungsi dari alat-alat praktikum tersebut.

\section{F. Kesimpulan dan Saran}

Berdasarkan hasil penelitian dan pengelolaan data maka dapat disimpulan bahwa kesalahan-kesalahan yang sering dilakukan oleh mahasiswa dalam melaksanakan praktikum Konsep IPA 2 adalah: kesalahan merangkai alat sebanyak 24 mahasiswa (60\%); kesalahan paralaks dan kesalahan penentuan skala masing-masing sebanyak 20 mahasiswa (50\%); dan kesalahan titik nol sebanyak 14 mahasiswa (35\%). Kesalahan yang memiliki proporsi terbesar yang dilakukan oleh mahasiswa dalam melaksanakan praktikum Konsep IPA 2 adalah kesalahan merangkai alat.

Berdasarkan hasil penelitian ditemukan beberapa kesalahan yang sering dilakukan oleh mahasiswa dalam melaksanakan praktikum, sehingga untuk menanggulangi permasalahan ini diharapkan kepada guru-guru IPA sekolah dasar dan menengah agar memberikan pengalaman praktikum dalam pembelajaran, agar siswa memiliki pengetahuan dasar tentang alat-alat laboratorium serta fungsi dari alat-alat tersebut. Begitu juga dosen-dosen pemberi matakuliah IPA, selain mengajarkan konsep materinya juga harus mengajari praktikumnya di laboratorium. 


\section{DAFTAR RUJUKAN}

Amin, M. 1999. Pedoman Laboratorium dan Praktikum Jurusan MIPA. Jakarta: Depdikbud.

Slamet, A. 2008. Praktikum IPA. Jakarta: Dirjen Dikti Depdiknas.

Sugiharto, B. 2009. Optimalisasi Pengelolaan Laboratorium IPA SMP (Online). (http://www.guruonline.com, diakses 17 Februari 2009).

Djonoputro, B. D. 1984. Teori Ketidakpastian. Bandung: ITB.

Williams, J. D. 2011. How Science Works: Teaching and Learning in the Science Classroom. New York: Continuum International Publishing Group.

Osborne, J., dan Dillon, J. 2010. Good Practice in Science Teaching What Research Has to Say 2nd Edition. UK: Bell \& Bain Ltd.

Kerlinger, F., N. 1993. Asas-asas Penelitian Behavioral. Terjemahan oleh Landung R. Simatupang. Yogyakarta: Gadjah Mada University Press.

Sutrisno, L., Kresnadi, H., dan Kartono. 2007. Pengembangan Pembelajaran IPA $S D$. Jakarta: Depdiknas.

Naim. 1992. Pengantar Laboratorium IPA. Jakarta: Depdikbud.

Sutarno, N. 2005. Materi dan Pembelajaran IPA SD. Jakarta: Universitas Terbuka.

Levinson, R. 2005. Teaching Science The Open University Postgraduate Certificate of Education Science. New York: Routledge.

Soejoto dan Sustini. 1993. Petunjuk Praktikum IPA Dasar. Jakarta: Depdikbud.

Suryabrata. 1983. Metodologi Penelitian. Jakarta: PT Raja Grafindo Persada.

Sudjana, N. 1999. Metoda Statistika . Bandung: Tarsito.

Wirasasmita. 1999. Pengantar Laboratorium IPA. Jakarta: Depdikbud. 